NOAH BAR GOSEN

Higher Studies Israel

\title{
ON THE CONTINUUM BETWEEN EDUCATIONAL AND ACADEMIC GOALS - RESULTS FROM A QUALITATIVE RESEARCH ON ISRAELI HIGH SCHOOL HOMEROOM EDUCATORS AND SUBJECT TEACHERS
}

\begin{abstract}
Bar Gosen Noah, On the Continuum Between Educational and Academic Goals - Results from a Qualitative Research on Israeli High School Homeroom Educators and Subject Teachers [O ciągłości celów wychowawczych i edukacyjnych - wyniki badań jakościowych przeprowadzonych na wychowawcach i nauczycielach przedmiotów w Izraelu]. Studia Edukacyjne nr 42, 2016, Poznań 2016, pp. 435451. Adam Mickiewicz University Press. ISSN 1233-6688. DOI: 10.14746/se.2016.42.25
\end{abstract}

This research project presents different role perceptions regarding educational and academic aims, among high school instruction personnel.

Since its foundation the Israeli education system has defined its role as a socialization agent as well as an academic institution. As national and international achievement tests became more widespread, the focus on academic aspect increased and the influence of academic excellence on school grading can be seen as more influential in comparison to educational achievements.

Semi-structured interviews of 14 high school teachers - homeroom educators and subject teachers were conducted. Results show that homeroom educators put more emphasis on educational aims while subject teachers put more emphasis on academic achievements. Their definition of success was a mixture of both objectives. Homeroom educators tend to apply educational inclusive practices while subject teachers tend to apply instructional ones.

International research emphasizes the importance of educational aims and inclusive practices in promoting academic achievements for all (OECD, 2010). The emphasis on evaluation and assessment of academic achievements may results in exclusive practices. These results suggest that adding educational achievements to schools' evaluation scales can encourage all instruction personnel to promote educational aims and inclusive practices as well as academic ones, thus contributing to schools' performance in evaluation tests.

Key words: homeroom educators, subject teachers, educational aims, achievements' evaluation, role perception, inclusive practices

Since its establishment, side by side with the establishment of the state of Israel, the Israeli education system had emphasized the importance of the 
school system as a major socialization agent. ${ }^{1}$ The importance of the education system in the process of rebuilding a nation emphasized educational aims over academic goals. ${ }^{2}$ The rise of the standard movement during the 80 's and the implementation of national and international tests, put the focus on academic achievements, thus focusing the instructional process on achieving a matriculation degree. ${ }^{3}$ Today, it can be stated that in general, high schools in Israel are evaluated mostly on the basis of their students' matriculation scores. ${ }^{4}$ As a result, and in contradiction to the common perception in the beginning of the Israeli education system, academic achievements aims, especially in high schools, surpass educational aims.

\section{Educational aims and Academic achievements - two aspects in school role definition}

The educational process is an expression of social desire to raise future generations successfully. ${ }^{5}$ Its role focuses on preparing the young generation for their adult roles: as civilian, workers, family members and citizens. ${ }^{6}$ School objectives are defined based on social assumptions regarding the desired nature of adults in terms of both social-emotional aspects as well as intellectual aspects.7 Thus school should be responsible for the students acquiring academic skills and knowledge, as well as social and ethical skills which together pave the way to becoming a contributing member of society. It can be stated that schools as socialization agents are evaluated by their students' prospects to integrate successfully in the adults' world. ${ }^{8}$ School practices and activities can be defined by two main processes: ${ }^{9}$ the first one is Educating, meaning cultural, ethical and social instruction as well as per-

\footnotetext{
${ }^{1}$ R. Alboym-Dror, The Hebrew Education in Eretz Yisrael, Jerusalem 1986.

2 Ibidem.

${ }^{3}$ G. Yair, D. Inbar, Achievements' standardization in education: a check point, a mile stone or an obstacle, [in:] Toward Educational Evolution? Ed. D. Inbar, Jerusalem 2006. p. 145-130.

${ }^{4} \mathrm{M}$. Razer et al., Israeli high school teachers' perceptions and attitudes towards a pedagogy of inclusion, International Journal of Inclusive Education, 2015, p. 1-21.

${ }^{5}$ F. Smith, A.S. Harison, Principals of Class Teaching, Tel Aviv 1958.

6 S. Bowles, H. Gints, Schooling in Capitalistic America, Educational Reforms and the Construction of Economic life, New York 1977, Ch. 1.

7 P.J. Higginbothan, Philosophy and the Teacher, London - Henley - Boston 1976, Ch. 4.

8 S. Brint, School and Societies, California 2006.

${ }^{9}$ I. Bakshi-Brosh, The Significance of the Roles of Homeroom Educators and Subject Teachers in the Israeli Education System, Negev 2005.
} 
sonal growth. ${ }^{10}$ The second process is Teaching, meaning a deliberate and intentional processes of passing knowledge to learners and extending their learning abilities.11 While educational processes result in acquiring knowledge regarding social life, personal growth and excellence, and human values, ${ }^{12}$ teaching results in acquiring knowledge and academic achievements. While educational results are less tangible and measurable by their nature, academic results are easily evaluated and measured. The dispute regarding the importance of each goal is an ongoing one. It is embedded in societal perception regarding education and its purposes. Those who emphasize educational aims will promote school aspects such as caring, ${ }^{13}$ affective teaching 14 and attending to child's holistic needs. ${ }^{15}$ Others, who emphasize academic achievements, will promote school aspects such as accountability, standards and evaluation tests as measurements of schools' success. ${ }^{16}$ Since schools operate under the mandate society gives them, it is fair to say that whether these goals should be seen contradicting or complementing lies very much in the eyes of society.

\section{On the continuum between educational and academic goals in the Israeli education system}

The Israeli school system can be defined as a mandatory national education system. Its evolvement occurred as part of the establishment of the Jewish state, since the first pioneers returned to their land. ${ }^{17}$ Teachers and schools wished to take part in defining the characteristics of the educational system's products according to the national vision. ${ }^{18}$ The teachers led the

10 T. Adar, An Introduction to Education and Teaching, Gomeh - Science and Research books, Tel Aviv 1974, p. 9-23.

${ }_{11}$ M. Oakeshot, Learning and Teaching, [in:] The Concept of Education, Ed. R.S. Peters, London 1966, p. 156-176.

${ }^{12}$ N. Aloni, Introduction, Preface: The Philosophy as the Love of Wisdom and the Yearning for Comprehensive Understanding in the Art of Life, [in:] Becoming Human, Philosophy of Education: An Anthology, Ed. N. Aloni, Tel Aviv 2005, p. 74-84.

${ }^{13}$ N. Noddings, The Challenge to Care in Schools an Alternative Approach to Education, New York - London 1992.

${ }^{14}$ S. Sherman, Responsiveness in Teaching: Responsibility in its Most Particular Sense, The Educational Forum, 2004, 68, p. 115-124.

15 J. Korczak, The Child Religion, Israel 1978.

${ }^{16}$ G. Yair, D. Inbar, Achievements' standardization in education.

17 N. Reichel, The Story of the Israeli Education System, Between Centralism and Distribution, Clarity and Ambiguity, Replication and Ingenuity, Israel 2008.

18 A. Kleinberger, Society, Schools and Progress in Israel, Oxford 1969; T. Tadmor-Shimon, National education and formation of state in Israel, Negev 2010. 
fight for the revival of the Hebrew language, while the newly born teachers' organization became an influential body which molded the new educational system according to Zionist ideology. ${ }^{19}$ Education was considered as important as working the land and the establishment of new settlements to the revival of the Jewish state and identity. ${ }^{20}$ The Zionist revolution became the platform on which Hebrew teachers built the foundation for the national education system. ${ }^{21}$ Education was an instrument to the implementation of the national ideology and teachers were the professionals to carry out this mission. 22

But schools in Israel still carried out their traditional role of passing knowledge to the younger generation. The newly emergent education system wished to endow the progressive values of the Jewish Enlightenment movement - Haskalah - which promoted secular studies as opposed to Jewish traditional education. Schools' curriculum combined educational themes together with academic subjects. ${ }^{23}$

As educational aims were equal, if not superior to, academic aims at the beginning of the educational system in Israel, the Israeli educational system made a clear differentiation between the role of the educator (Mechanech), who focuses on the educational aspects, and the role of the subject teacher (Moreh), who focuses on the instructional/ teaching aspects of his/her specific subject. 24

The 'Mechanech' was chosen to lead the education process for the new Israeli generation. The 'mechanech' passes values to the students and acts as a role model to them. ${ }^{25}$ His responsibility toward his students is holistic in nature. ${ }^{26} \mathrm{~A}$ 'Mechanech' - homeroom educator - is responsible for all personal, social, behavioral and ethical aspects of the students educational process, as individuals and as a group. He is the head teacher of his class and responsible to communicate with subject teachers who teach his class. $\mathrm{He}$ is also responsible for maintaining contact with his students' parents. ${ }^{27}$

${ }^{19}$ R. Alboym-Dror, The Hebrew Education.

${ }^{20}$ M. Carmon, The Teachers' Organization and the Education Problem in the 'Yishuv' Israeli teachers organization Jubilee Book, Eds. D. Kimhi, L.Y. Riklis, 1956, p. 418-435.

${ }^{21}$ R. Alboym-Dror, The Hebrew Education.

22 Y. Silbert. The teacher's professional status in Eretz Yisrael 1892-1913, Tel Aviv 1995, p. 45-58.

${ }^{23}$ N. Raichel, The Story of the Israeli Education System.

24 Ministry of Education, 2016.

${ }^{25}$ N. Reichel, The Story of the Israeli Education System.

26 S. Zidkiyaho et al., Classroom Management, Mofet Institute 2008; L. Notov, Homeroom educator LTD, Israel 2006.

${ }^{27}$ L. Notov, What is Between Maslow and Scehin? Organizational Engagement Model as an Expression of Culture, Needs and Management: The Case of Role design of the Israeli High School Home- 
Evidently, the Mechanech role definition extends far beyond the role definition of a teacher. While teachers concentrate on passing knowledge to their students, the "Mechanech" - the homeroom educator - is responsible for promoting the individual's personal growth, transmitting the desired social values as well as the common cultural heritage. ${ }^{28}$ In the Israeli education system the 'Mechanech' role was designed according to the 'Chalutz' a Jewish pioneer - myth: A Zionist person, who is committed to the ideals of reviving the Jewish state. ${ }^{29}$ Though the myth itself may have lost its dominance in Israeli society, the role of the homeroom educator is still a key figure and a central role in Israeli schools. Until today he is responsible for social and moral education, as well as students' personal growth. ${ }^{30}$

The higher status of the homeroom educator among instruction personnel emphasizes the importance given to educational aims in the early years of the Israeli education system. Today, homeroom educators still hold a dominant position within the education system. They are still expected to carry out their complicated and valuable role, which emphasizes the achievement of educational goals.

Since the establishment of the Israeli educational system, apparent achievements' gaps among distinctive population were evident. Intervention processes such as the integration, and the establishment of secondary schools during the 60's were not successful in eliminating those achievements gaps. ${ }^{31}$ The rise of the standards movement during the 80 's only increased the emphasis on academic achievements, ${ }^{32}$ and further highlighted and deepened those gaps as students from low socio-economic background fell further behind.

Evaluation processes have entered the education system in order to assess academic and educational achievements. Academic aims are evaluated through standardized national and international tests that rank schools according to their achievements in Hebrew, English, Mathematics and science. ${ }^{33}$ Matriculation tests' results are also considered a ranking instrument for schools.

room Teacher, Haifa 2011. S. Zidkiyaho, et.al., Classroom Management; L. Notov, Homeroom educator LTD.

${ }^{28}$ T. Adar, An Introduction to Education and Teaching.

29 D. Gordon, W.I. Ackerman, The Mechanech: Role Function and Myth in Israeli secondary Schools, Comparative Education Review, 1984, 28, 1, p. 105-115.

${ }^{30}$ I. Bakshi-Brosh, The Significance of the Roles of Homeroom Educators.

${ }^{31}$ N. Reichel, The Story of the Israeli Education System.

32 G. Yair, D. Inbar, Achievements' standardization in education, p. 145-130.

${ }^{33}$ Rama (Israel National Authority for Measurement and Evaluation in Education), Ministry of Education, Israel 2016. 
Educational aims are evaluated through national surveys of school climate, attached to the Meitzav ${ }^{34}$ tests. Also the Ministry of education publishes schools ranks based on moral/social achievements such as draft rates, volunteering work, inclusive education, etc. 35

The entrance of comparative tests reinforced the importance of academic achievements, thus focusing the instructional endeavors on achieving a matriculation degree, or raising the school average in achievements' evaluation tests. ${ }^{36}$ Today, it can be stated that in general, high schools in Israel are evaluated mostly on the basis of their students' matriculation scores. ${ }^{37}$ As a result, and in contradiction to the common perception in the beginning of the Israeli education system, it seems that more emphasis is given to academic achievements in compare to educational aims, especially in high schools.

Another effect to the continuing achievements' gaps based on socioeconomic characteristics was the rising need for inclusive education. Schools need to apply more inclusive practices in order to enable students from low socio economic background to obtain higher academic achievements. ${ }^{38}$ The role of the homeroom educator who, by definition, establishes a closer personal relationship with his students, was recognized by the OECD as an important role to enhance academic achievements. ${ }^{39}$ Other inclusive practices rely on a more holistic perception of the students and take into consideration their personal characteristics and social context while guiding them through educational processes. ${ }^{40}$ Inclusive practices can also reflect academic aspects like tutoring and planning differentiated instruction methods in order to address students' different learning needs. ${ }^{41}$

${ }^{34}$ A Hebrew acronym for Measures of School Effectiveness and Growth. The MEITZAV standardized achievement tests are intended to examine to what extent elementary and junior high school students meet requirements based on the curriculum in four core subjects: science and technology, English, mother tongue (Hebrew/Arabic), and mathematics, at two grade levels (5th and 8th). Tests are administered in mother tongue competency in the second grade as well (M. Razer et al., Israeli high school teachers' perceptions and attitudes, p. 17). When the tests are external, i.e. checked and evaluated by external personnel from the Ministry of Education, a survey checking school climate is added to the tests.

${ }^{35}$ Ministry of Education, Israel 2016.

${ }^{36}$ G. Yair, D. Inbar, Achievements' standardization in education.

${ }^{37} \mathrm{M}$. Razer et al., Israeli high school teachers' perceptions, p. 1-21.

${ }_{38} \mathrm{M}$. Razer et al., Inclusion and Achievement in Education: Contradictory or Complementary Goals? Dvarim Oranim College, 2013, 6, p. 11-28.

39 OECD, Strong Performers and Successful Reformers in Education: Lessons from PIZA for the United States. 2010, http://dx.doi.org 10/1787/9789264096660-en [access: 2013].

${ }^{40} \mathrm{M}$. Razer et al., Israeli high school teachers' perceptions.

${ }^{41} \mathrm{~S}$. Carrington, J. Elkins, Bridging the gap between inclusive policy and inclusive culture in secondary schools. Support for Learning, A Journal for the National Association from Special Educational Needs, 2002, 17(2), p. 51-57. 


\section{Research Question}

The Ministry of education's annual goals declaration includes academic aims such as raising achievements and aspiring to excellence. It also includes educational aims such as reinforcing moral and civil excellence and inclusive education resulting in adjusting educational and instructional processes to students characteristics and needs. ${ }^{42}$

Instruction personnel consisting of homeroom educators and subject teachers is in charge of carrying out these stated goals. Based on the differences in role definition, the existence of different perceptions regarding the implementation of these goals can be assumed. The research question is as followed: What are the differences regarding perception of aims and the implementation of inclusive practices among high school homeroom educators and subject teachers?

By role definition, homeroom educators will be responsible, mainly, for the implementation of educational goals, resulting in applying more inclusive practice. Subject teachers, on the other hand, will concentrate mainly on achieving academic goals resulting in applying less or different inclusive practices. Their different emphases regarding these goals can result in a different definition for students' success. It can be assumed that homeroom educators will emphasize educational aspects of success, while subject teacher will emphasize academic aspects of success. Inclusive practices, such as relating to the students' personal and social needs, ${ }^{43}$ holding a more holistic perception of the students and taking into account their background characteristics and life events, ${ }^{44}$ will be perceived as associated more to the role of the homeroom educator than to the role of the subject teacher.

\section{Research Population}

Twelve semi-structured interviews were held with six homeroom educators $(2 \mathrm{~m}, 4 \mathrm{f})$ and six subject teachers (6f). (Age disparity homeroom educators 38-55. Age disparity subject teachers 27-64 yrs. Seniority disparity homeroom educators 13-26 yrs. Seniority disparity subject teachers 3-30 yrs).

42 Ministry of Education, MATANA (Planning, administration, and preparation package for 2015/2016), Pedagogic Administration. (Hebrew) http://cms.education.gov.il/Education CMS/Units/MinhalPedagogi/matana/2015.htm [access: May 2016].

${ }^{43} \mathrm{M}$. Razer et al., Israeli high school teachers' perceptions.

${ }^{44}$ F. Mor, Seeing the Children - Guide to Creating a Nurturing Educational - Therapeutic Environment for At-risk Students, Jerusalem 2006. 
Complementary interviews were held with a school counselor and a school's vice principal (2f, Age disparity $44-50$ yrs.).

All of the interviewed teachers work in a rural comprehensive regional high school in the Jewish sector, spanning four years of learning $\left(9^{\text {th }}-12^{\text {th }}\right.$ grades). School population includes approximately 800 students and 100 teachers. Teachers' population characteristics are very similar to students' population. ${ }^{45}$

School population SES is average. External measures such as matriculation certificate rates, matriculation tests' grades $^{46}$ and military drafting rates $^{47}$ rank the school above average in comparison with other Israeli high schools within the Jewish sector. ${ }^{48}$ The school is defined as a regular school and it includes three classes in each grade level for students with different levels of learning abilities. All students are aimed to achieve a partial or full matriculation degree.

Homeroom educators function as class "managers". They have a full responsibility for the students in their class. They meet their class's students every morning for 15 minutes. At this session the homeroom educator checks attendance, reviews behavioral reports from the day before, passes information or discusses current events. In addition, s/he holds two homeroom hours in his/her class as part of a planned educational program. In these lessons ethical and social values and events are discussed as well as current events. The homeroom educator accompanies his/her students to all social and extra-curricular activities taking place as part of the school year, including field trips. In addition, all homeroom educators teach as subject teachers in different classes.

Subject teachers teach their classes according to hours assigned to that subject (2-4 lessons per week). Subject teachers who teach in stratified subjects (Math or English for example) or a specific subject like Physics or Electronics, which is not a core subject, will meet a selected group of students every lesson, but never the whole class. As a whole, a homeroom educator is responsible for 20-35 students in his homeroom class. A subject teacher meets several classes, thus his/her instructional responsibility scope can be over a hundred students.

${ }^{45}$ School site [access: January 2015].

46 Ibidem.

47 K. David, The North Says Yes to the IDF; http://www.mynet.co.il/articles/0,7340,L3999693,00.html [access: August, 2015].

${ }^{48}$ School site [access: January 2015]. 


\section{Research Methods}

Qualitative interviews ${ }^{49}$ using semi - structured interviewing method with open questions, were held with every teacher individually. The emphasis on qualitative methodology was chosen in order to obtain a naturalistic and descriptive data which, through an inductive analytic process, can bring out the meaning the teachers give to their role definition, behaviors and attitudes. ${ }^{50}$

The interviews were based on questions regarding specific foci that are part of the teachers' role scope. Role definition - i.e. homeroom educator or subject teacher, defined goals, values and successes within that role, evaluation of professional training prior and during their teaching experience, relationship with students, peers and students' parents, attitudes toward disciplinary issues, inclusive practices, and their perception of the students and their responsibility toward them.

All interviews took place in the second trimester of the school year. Each interview length was approximately one hour. After obtaining interviewees' consent, all interviews were documented.

Due to existing personal and professional relationships with teaching staff, special precautious had to be taken in order to remain neutral and objective during the interviews. As a whole, the interviewees were very open and candid. The interviewed teachers expressed their gratitude for the opportunity to reflect on their profession. The interviewees spoke their mind and reflected on their professional behaviors, values and attitudes. The position of an interested listener was kept without imposing or directing the interviewed teachers. ${ }^{51}$

After coding the answers, the qualitative analyses revealed three prominent themes: defined objectives, defined success and the application of inclusive practices. The qualitative analyses revealed three prominent themes: The first theme relates to the teachers' definition of main objectives, i.e. educational aims or academic achievements. The second theme relates to the teacher definition of success, i.e. education centered, or achievements' centered. The third theme relates to implementation of inclusive practices and the differences in applied practices among homeroom educators and subject teachers.

${ }^{49}$ R.K. Yin, Qualitative Research from Start to Finish, New York 2011.

50 R.C. Bogdan, S.K. Biklen, Qualitative Research for Education - an Introduction to Theories and Methods, 5th edition, U.S.A. 2007.

${ }^{51}$ R.K Yin, Qualitative Research. 


\section{Analysis}

Analysis will be presented in three sections: In the first section each theme will be presented together with answer distribution and prominent relevant quotes. At the second section an in-depth discussion will be presented, in which themes and leading quotations will be analyzed within a theoretical context. Lastly, generalizations and implications will be concluded as practical implications, further research suggestions and a foundation for drafting a quantitative questionnaire which will be the center of the complete research.

\section{First theme: Defined objectives}

Educational and academic objectives co-exist in schools' annual activity planning. These objectives can be seen as combined or separated, complementing or contradicting. Homeroom educators' role definition clearly emphasizes educational aims. Subject teachers' role definition clearly emphasizes academic achievement. So how are these objectives perceived and how do they intersect?

All interviewed teachers acknowledged the existence of educational and academic objectives, and perceived them as part of their role. Homeroom educators, while acknowledging the importance of academic aims, tend to put more emphasis on educational objectives. "My first objective as a homeroom educator is to bring them to the finish line, not necessarily a full matriculation degree but as many finals as possible... the final comes second." (Y, He, 50) "I want all of them to have full matriculation degree, with the best marks possible... It enables them to realize they can do great things. That they are amazing people..." (D, HE, 48). "My goal is to help them pass these four years in the best way socially, scholastically and emotionally." (D, HE, 45).

Subject teachers, while acknowledging the importance of educational aims, tend to emphasize the emphasized academic aims more. "My first objective is that they will pass the finals with good enough grades... I don't just pass them materials, I am dealing with youngsters.. Every teacher is an educator, I find it very true." (I, ST, 55). "Our main role is to prepare them for the finals.. But I don't give up on making them interested... I try all kinds of instructional methods.". (Y, ST, 64). To teach them linguistic skills... to pass the finals... Inside the classroom I want a good learning atmosphere...Cooperation between teacher and students. Cooperation among students in learning the language..." (L, ST, 56) 


\section{Second theme: Defined success}

Interviewed teachers were asked to define their perception of success. Since school objectives is a mixture of academic and educational aims, the definition of success as perceived by the teachers, can imply on their perception of the relative importance of academic vs. educational aims.

As a whole there weren't obvious differences among homeroom educators and subject teachers in defining what they perceive as success. All interviewees acknowledged the importance of a matriculation degree to their students' lives, and as a symbol of a successful end of the high school long journey. Nevertheless, they also acknowledged the importance of personal growth and social success which can be perceived as educational objectives. Their answers revealed a mixture of educational and academic achievements, without a firm determination of 'what comes first'.

An example for answers given by homeroom educators: "Success in the final exams can be a parameter. The feeling of belonging they have developed toward the institution." (H, HE, 55) "For the long run it is all about succeeding in tests the final exams. Students who are failing less. They believe in themselves. (Y, HE, 50). "The children feel that they succeeded in finishing high school... They are o.k. socially, they are o.k. They have succeeded in what they have learned" (D, HE, 48)

An example for answers given by subject teachers: "When no one dropped out, when they are happy, and come to all the lessons, and of course the grades...." (M. ST, 48). "When the students pass their final exams... When I see that what I taught them entered their lives." (Y, ST, 64). "To bring the students to success out of love for the subject... We prepare them for the finals, but the learning process is more important..." (H, HE, 27)

\section{Third theme: applied inclusive practices}

Inclusive practices serve as an instrument to help students with various characteristics to become meaningful participants in the learning and educating processes which take place in school. Inclusive practices can emphasize educational and interpersonal aspects such as establishing a close interpersonal relationship with the students, perceive them in a holistic manner and mediating between them and other teachers / students or students' parents in times of need. Inclusive practices can emphasize academic aspects such as tutoring, differentiated instruction practices aiming to ease the learning process for various students.

All interviewees reported implementing inclusive practices. Homeroom educators applied practices more educational and interpersonal in nature. "I conduct many conversations with the students... I do a lot of mediation between 
them and the subject teachers... I guide him how to speak in order to achieve his goal." (D, HE, 48). "There were many activities to enhance social cohesion, caring and mutual help. ...to get to know the students personally." (H, HE, 55). "I keep constant contact with them, even outside school's district...I am their answer for everything. I try to get to know their personal lives as well" (Y. HE. 50).

Subject teachers reported implementing inclusive practices that are more instructional and academic by nature. "We meet with many students. It is very difficult to establish a state of closeness. I try, in my classroom, to establish an atmosphere of... conversations, group work. Tutoring helps establishing relationship because we sit one on one" (L, ST, 56). "I show them that I take their difficulties into consideration. If they couldn't submit their papers I made it easier for them..." $(\mathrm{H}, \mathrm{ST}, 27)$ "I rely on my professional knowledge acquired during my studies to adjust my lessons to students' characteristics." (M, ST, 33)

As the analysis shows, both educational and academic aims are taken into consideration by homeroom educators and subject teachers when they define their perception of objective and success. Results show differences in emphasis of role objectives among the interviewees. Both homeroom educators and subject teachers acknowledged the importance of both objectives. However, homeroom educators emphasized educational objectives while subject teachers emphasized academic aims. The interviewees' definition of success was quite similar, and portrayed a mixture of educational and academic aims. All interviewees applied inclusive practices. Homeroom educators tend to apply educational and inter-personal inclusive practices while subject teachers tend to apply inclusive practices more instructional and academic in nature.

\section{Discussion}

Since its establishment, the Israeli education system aimed to pursue educational objectives. ${ }^{52}$ During the first years these objectives seemed to surpass academic objectives. Nevertheless, schools were required to address scholastic needs as well, to a varied and highly heterogenic student population. ${ }^{53}$ The instructional personnel - comprised of homeroom educators as the leading educational figures and subject teachers as subject professionals - were assigned to be educators and teachers of the new Israeli generation. ${ }^{54}$ Soon, distinctive achievements gaps were apparent based on socio economic

\footnotetext{
52 R. Alboym-Dror, The Hebrew Education.

${ }^{53}$ N. Reichel, The Story of the Israeli Education System.

${ }^{54}$ D. Gordon, W.I.. Ackerman, The Mechanech: Role Function and Myth.
} 
characteristics. ${ }^{55}$ The rise of the standards movement during the 80 's, only increased the emphasis on academic achievements. The achievement of a matriculation degree became the prominent objective through which high school achievements are measured. ${ }^{56}$ International and national achievements' tests assess not only the academic achievements of Israeli students, but they also reflect the changing achievements' gap as well as school climate parameters and dropping rates. ${ }^{57}$ Today, academic and educational aims co-exist in the Israeli education system. Academic aims focus on raising the achievements average in national and international tests. Educational aims emphasize an inclusive education alongside national and ethical objectives. In light of this, it is important to review how homeroom educators and subject teachers define their professional objectives.

As can be expected, different role perception resulted in different defined objectives. Homeroom educators, who by role definition are responsible for scholastic, personal, social, and ethical aspect of the education process, ${ }^{58}$ acknowledge both objectives but emphasize educational ones. Subject teachers, who by role definition are responsible for learning processes and academic results, ${ }^{59}$ acknowledge both objectives but emphasize academic ones.

As for defined success, the differentiation between roles definition was less obvious. Yair and Inbar ${ }^{60}$ claim that the rise of the standard movement put the focus on academic achievements, thus the matriculation degree became the main objective of high school studies, and the basis for school evaluation. Razer and co. ${ }^{61}$ claim that putting the focus on academic achievements, changes school discourse into an academic one. Based on these claims, it is no wonder that homeroom educators and subject teachers both identified academic results and matriculation degree's achievement as a clear sign of success. On the other hand, both homeroom educators and subject teachers recognized the importance of educational aims and indicated them as a sign of success. How is it that when speaking of defined aims, role differentiations were evident, but when speaking of defined success, role differentiations were missing?

${ }^{55}$ N. Reichel, The Story of the Israeli Education System.

${ }^{56}$ G. Yair, D. Inbar, Achievements' standardization in education.

57 Rama, (Israel National Authority for Measurement and Evaluation in Education).

${ }^{58}$ Ministry of Education, Teaching staff work regulations. (Hebrew) http://cms.education. gov.il/EducationCMS/UNITS/Sherut/Takanon [access: January, 2015].

59 Ibidem.

${ }^{60}$ G. Yair, D. Inbar, Achievements' standardization in education.

${ }^{61} \mathrm{M}$. Razer et al., Inclusion and Achievement in Education. 
Several explanations can be suggested for this finding. Defined objectives can be perceived as more formal and role definition's based while perception of success may be perceived as a more personal view. The statement "every teacher is an educator", by one of the interviewees (I, ST, 55) can represent a common view among the interviewees. It is also possible, that educational discourse in this specific school emphasizes educational and academic aims.

The struggle for academic aims and increased achievements can lead to an exclusive discourse and the application of exclusive practices ${ }^{62}$ especially toward students with difficulties adjusting to learning procedures. Razer and co. $^{63}$ differentiated between behavioral problems that require teachers' intervention and academic issues that require teachers' intervention. Though both problems affect students' learning they require different intervention practices. Interventions using inclusive practices aimed at personal and behavioral problems can be defined as educational inclusive practices. Interventions using inclusive practices aimed at problems in the learning process can be defined as instructional or academic inclusive practices.

The analysis shows that homeroom educators tend to apply educational inclusive practices such as interpersonal relationships and mutual conversations based on holistic perception of the students. Subject teachers tend to apply instructional inclusive practices such as tutoring and adjusting scholastic demands to students' characteristics.

International research emphasizes the importance of educational aims and inclusive practices in promoting academic achievements for all. ${ }^{64}$ The importance of inclusive practices, and the implementation of appropriate teaching methods based on students' different characteristics is a proven strategy to enhance students' achievements and diminishing the achievement gap. ${ }^{65}$ An emphasis on teacher - student relationships ${ }^{66}$ and the role of the homeroom educator, i.e. a teacher that by his/her role definition establishes closer and more personal relationships with the students and thus leads them to higher academic achievements, ${ }^{67}$ were also recommended as strategies to enhance the achievement of educational and academic aims in

\section{Ibidem.}

${ }^{63} \mathrm{M}$. Razer et al., Israeli high school teachers' perceptions and attitudes.

${ }^{64}$ OECD, Strong Performers and Successful Reformers in Education: Lessons from PIZA for the United States. 2010, http://dx.doi.org 10/1787/9789264096660-en [access: 2013].

65 OECD, PISA 2009, Results: overcoming social background', Equity in Learning Opportunities and Outcomes', vol. 5.

66 OECD, PISA 2012, Results: Ready to Learn - Students' Engagement, Drive and Self-Beliefs, OECD Publishing, 2013.

67 OECD, Strong Performers and Successful Reformers in Education. 
a heterogenic student population. ${ }^{68}$ Thus a combination of educational and academic inclusive practices promote students' learning processes as a whole.

\section{Summary and conclusions}

High school years are usually the finish line of a mandatory education system. The reward that awaits the students is the matriculation degree. International and national tests established that degree as a symbol of success or failure in the education system, as well as a mean for comparison among students, schools (and states).

Many resources are spent in order to enhance students' achievements as a whole as well as diminishing the achievement gap based on socioeconomic characteristics which is prevalent in the Israeli education system. While focusing on achievements and academic aims can lead to exclusive education, inclusive education and practices can pave the way for better education and higher achievements for all.

The Israeli education system has two distinctive roles in it. Research shows that though their definition of success combines educational and academic aims, their emphasis on aims and inclusive practices is different. Homeroom educators tend to emphasize educational aims and apply educational inclusive practices. Subject teachers tend to emphasize instructional practices and apply instructional or academic inclusive practice.

National and international tests have promoted the importance of academic achievements. Adding educational aims and educational achievements parameters to national and international test, as part of school comparison and ranking can enhance the application of educational and academic inclusive practices, by all teachers and for the benefit of all students' population.

It should be taken into account that these results are based on a small sample of teachers who work in the same school. A larger scale research is advised to support and elaborate these findings.

Education is our gift for the next generation. We need to make sure we are giving it in the best way possible.

68 Ibidem. 


\section{BIBLIOGRAPHY}

Adar T., An Introduction to Education and Teaching, Gomeh - Science and Research books, Zerikover Pub., Tel Aviv 1974. (Hebrew)

Aloni N., Preface: The Philosophy as the Love of Wisdom and the Yearning for Comprehensive Understanding in the Art of Life, [in:] Becoming Human, Philosophy of Education: An Anthology, Ed. N. Aloni, Mofet Institute, Hakibutz Hmeochad Pub., Tel Aviv 2005, p. 7484. (Hebrew)

Alboym-Dror R., The Hebrew Education in Eretz Yisrael, Yad Yitchak Ben Tzvy Pub., Jerusalem 1986. (Hebrew)

Bakshi-Bros U., The Significance of the Roles of Homeroom Educators and Subject Teachers in the Israeli Education System, Ben Gurion University of the Negev, Negev 2005. (Hebrew)

Bar Gosen N., Different Role Perceptions and Student - Teacher Relationship characteristics Among High School Homeroom Educators and Subject Teachers' Results from a Qualitataive Research, Studia Edukacyjne, 2015, 36, p. 381-400.

Bogdan R.C., Biklen S.K., Qualitative Research for Education - an Introduction to Theories and Methods, 5th edition, Pearson Education Inc., U.S.A. 2007.

Bowels S., Gints H., Schooling in Capitalistic America, Educational Reforms and the Construction of Economic life, Basic Books Inc., New York 1977.

Brint S., School and Societies, Stanford, California 2006.

Carmon M., The Teachers' Organization and the Education Problem in the 'Yishuv' (prior to the establishment of the state of Israel - N.BG), Israeli teachers organization Jubilee Book, Eds. D. Kimhi, L.Y. Riklis, 1956. (Hebrew)

Carrington S., Elkins J., Bridging the gap between inclusive policy and inclusive culture in secondary schools. Support for Learning, A Journal for the National Association from Special Educational Needs, 2002, 17(2).

David K., The North Says Yes to the IDF; http://www.mynet.co.il/articles/0,7340,L3999693,00.html [Access: August, 2015]. (Hebrew)

David K., Kibutzim and Moahavim's Youth Favors the Army MyNet http://www.mynet. co.il/articles/0,7340,L-3999693,00.html [Access: May, 2016]. (Hebrew)

Gordon D., Ackerman W.I., The Mechanech: Role Function and Myth in Israeli secondary Schools, Comparative Education Review, 1984, 28, 1.

Higginbothan P.J., Philosophy and the Teacher, 1st pub., Routledge and Kegan Paul, London - Henley - Boston 1976, Ch. 4.

Kleinberger A., Society, Schools and Progress in Israel, Pergamon Press, Oxford 1969.

Korczak J., The Child Religion, Bet Lochamey Hagetaot and Hakibutz Hameochad Pub., Israel 1978. (Hebrew)

Ministry of Education, MATANA (Planning, administration, and preparation package for 2015/2016), Pedagogic Administration. (Hebrew) http://cms.education.gov.il/ EducationCMS/Units/MinhalPedagogi/matana/2015.htm [access: May 2016].

Ministry of Education, Teaching staff work regulations. (Hebrew) http://cms.education. gov.il/EducationCMS/UNITS/Sherut/Takanon [access: January, 2015].

Mor F., Seeing the Children - Guide to Creating a Nurturing Educational -Therapeutic Environment for At-risk Students, Ashalim, Ministry of Education, Jerusalem 2006. (Hebrew)

Noddings N., The Challenge to Care in Schools an Alternative Approach to Education, Teachers College Press, Columbia University, New York - London 1992. 
Notov L., Homeroom educator LTD, Litam Pub., Israel 2006. (Hebrew)

Notov L., What is Between Maslow and Scehin? Organizational Engagement Model as an Expression of Culture, Needs and Management: The Case of Role design of the Israeli High School Homeroom Teacher, Doctoral dissertation, Technion, Haifa 2011. (Hebrew)

Oakeshott M., Learning and Teaching, [in:] The Concept of Education, Ed. R.S. Peters, Routledge and Kegan Paul, London 1966.

OECD, PISA 2009, Results: overcoming social background', Equity in Learning Opportunities and Outcomes', vol. 5.

OECD, PISA 2012, Results: Ready to Learn - Students' Engagement, Drive and Self-Beliefs, OECD Publishing, 2013.

OECD, Strong Performers and Successful Reformers in Education: Lessons from PIZA for the United States. 2010, http://dx.doi.org 10/1787/9789264096660-en [access: 2013].

Raichel N., The Story of the Israeli Education System, Between Centralism and Distribution, Clarity and Ambiguity, Replication and Ingenuity, Mofet Institute Pub., Israel 2008. (Hebrew)

Rama (Israel National Authority for Measurement and Evaluation in Education), Ministry of Education, Israel 2016. (Hebrew)

Razer M., Mittelberg D., Motola M., Bar Gosen N., Inclusion and Achievement in Education: Contradictory or Complementary Goals? Dvarim Oranim College, 2013, 6. (Hebrew)

Razer M., Mittelberg D., Motola M., Bar Gosen N., Israeli high school teachers' perceptions and attitudes towards a pedagogy of inclusion, International Journal of Inclusive Education, 2015.

Sela A., Text-Books and Text people' What is the Role of the Mechanech in the Jewish Secular High School in Israel, and what is the Place of the Jewish Texts Within That Role? Doctoral dissertation, William Davidson Graduate School of Jewish Education, New York 2011.

Silbert Y., The teacher's professional status in Eretz Yisrael 1892-1913, Tel Aviv University, Tel Aviv 1995, p. 45-58. (Hebrew)

Sherman S., Responsiveness in Teaching: Responsibility in its Most Particular Sense, The Educational Forum, 2004, 68.

Smith F., Harison A.S., Principles of Class Teaching, Hadar Pub., Tel Aviv 1958. (Hebrew)

Tadmor Y., Homeroom Teachers as Key Figures in Education, [in:] Words That Teach: Collected Lectures and Articles, Ed. Y. Tadmor, Kedem Pub., Tel Aviv 1999, p. 200-217. (Hebrew)

Tadmor-Shimon T., National education and formation of state in Israel, Negev 2010.

Walla! News. Where do most moral and ethical high school students in Israel study? http:/ / news.walla.co.il/item/2880263 [entry: 11.8.2015].

Wentzel K.P., Are Affective Teachers Are Like Good Parents? Teaching Styles and Student Achievements in Early Adolescence, Child Development, 2002, 73, 1, p. 287-301.

Yair G., Inbar D., Achievements' standardization in education: a check point, a mile stone or an obstacle, [in:] Toward Educational Evolution? Ed. D. Inbar, Van Leer Institute, Jerusalem 2006.

Yin R.K., Qualitative Research from Start to Finish, Guilford Press, New York 2011.

Zidkiyaho S., Elam N., Fisherman S., Ronen H., Classroom Management, Mofet Institute 2008. (Hebrew) 